\title{
Burnout and Job Satisfaction Among Teachers in Chinese Independent Secondary School
}

\author{
Ooi Phaik Wei, Abdul Ghani Kanesan Abdullah \\ School of Educational Studies, Universiti Sains Malaysia, Penang, Malaysia \\ Email address: \\ wei_ooi26@yahoo.com (O. P. Wei),agk@usm.my (A. G. K. Abdullah)
}

To cite this article:

Ooi Phaik Wei, Abdul Ghani Kanesan Abdullah. Burnout and Job Satisfaction Among Teachers in Chinese Independent Secondary School. International Journal of Elementary Education. Vol. 5, No. 5, 2016, pp. 47-50. doi: 10.11648/j.ijeedu.20160505.11

Received: September 8, 2016; Accepted: September 18, 2016; Published: October 10, 2016

\begin{abstract}
This study aims to investigate the relationship between burnout and job satisfaction among teachers of Chinese Independent Secondary School (CISS) in Penang. The respondents consist of 175 teachers selected randomly from five CISS in Penang. Data from respondents was collected using a translated version of questionnaire consisting of 2 parts, Maslach Burnout Inventory - Educators Survey (MBI - ES) and Job Satisfaction Survey (JSS). The results show that the level of teacher burnout dimension of emotional exhaustion, and personal accomplishment are moderate. Whereas the burnout dimension of depersonalization was at low level. Overall, the level of job satisfaction amongst CISS teachers is at the moderate level. While the level of each dimension of job satisfaction indicates a moderate level such as salary, promotion, supervision, fringe benefits, contingent rewards, operating procedures, co-workers, nature of work, and communication. It shows there is a negative significant relationship between burnout and job satisfaction. The study suggests that school administrators should fully exploit how to avoid burnout at workplace in order to increase teachers' job satisfaction and performance.
\end{abstract}

Keywords: Burnout, Job Satisfaction, Chinese Independent Secondary Schools (CISS)

\section{Introduction}

Chinese Independent Secondary Schools (CISS) were established by the Chinese Ethnic in Malaysia early 19th century. Their main purpose is to provide education in Chinese. There are 60 CISS in Malaysia and it is open to all nationalities and backgrounds, including students from abroad. Most of the students in the CISS are Malaysian Chinese [1]. According to the Federation of Chinese School Management Board [2], the education system in the CISS is approximately equal to the education system in countries such as the United States, Japan, China, Taiwan and Scotland [2].

Currently, the education system throughout the world is undergoing rapid changes. Nevertheless these rapid changes also caused teachers' burden increased apart from teaching roles especially in CISS. Therefore teaching becomes increasingly challenging as since it is closely related to personality and human relations [3]. Teachers are forced to work beyond schedule, face role conflicts, lack of support from administrators and facing communication problems when interacting with students or parents as well as the lack of opportunity to develop themselves will create pressure leading to burnout [4, 5, 6]. According to Chernis [7], extreme pressure and dissatisfaction are the main causes that led to the occurrence of burnout syndrome. Burnout is an emotional exhaustion, depersonalization and also the lack of self-esteem that occurs in the teaching profession [7, 8, 9]. Meanwhile research by Tukiran [10] has identified that burnout would lead to dissatisfaction among teachers and so far there is little to be known about this relationship in private schools especially in Malaysian settings. The present study is an attempt to bridge this gap and is aimed at enhancing management skills of school managers in entertaining the ever-changing educational changes without having caused burnout among teachers in order enhancing high performance. Therefore, the major concern of this research is to examine the relationship between burnout and job satisfaction among teachers in CISS context.

\section{Literature Review}

Locke [11] defined job satisfaction as an emotion of being happy or comfortable with one's job, which results in the 
evaluation of work or working experiences. Meanwhile Demirtas [12] characterized that job satisfaction among middle and upper-level employees through the opportunity for promotion, success in their respective fields and smoothness in their workflow. According Aziri [13], job satisfaction is a feeling of success and achievement of workers in areas where they are operating. This feeling is geared more towards enhancing successful productivity in school. Job satisfaction is also indirectly related to performing a task with a happy, successful and adequate remuneration given to the efforts that have been made.

Burnout is often associated with satisfaction in the workplace. To avoid burnout, job satisfaction in individuals should be met. In the education, job satisfaction becomes important because the quality of education depends on the quality and efficiency of the teacher [14]. According to Tukiran [10], commitment and satisfaction are crucial factors in order to improve education.

Konert [15] conducted a study among 220 teachers in urban areas of Michigan found that teachers who experience job stress also suffers from emotional exhaustion and low personal accomplishment. In addition, the findings from Tan [16] and Apandi [17] showed that job satisfaction has a negative correlation with emotional exhaustion but correlated with the length of time a person is having a career. Meanwhile, Lim's study [18] showed that the level of stress experienced by teachers in Kedah, Malaysia was low and there was a significant inverse relationship between burnout and job satisfaction. Next, the findings of Anbar and Eker [19], which aims to identify the relationship between burnout and job satisfaction among academics in Turkey have found a negative relationship and statistically significant association between burnout and job satisfaction among academicians in Turkey. Meanwhile, a survey Azlina and Noryati [20] shows the low level of job stress and job satisfaction at a moderate level. The results of this study is consistent with the studies done by Norul Azlin [21] who studied the stress levels up to 120 teachers who teaches in exam classes in 10 primary schools which indicates that the overall level of stress at a low level. As conclusion the literature review shows that there is a strong relationship between burnout and job satisfaction among teachers

\section{Research Objectives}

This study aims to investigate the relationship between burnout and job satisfaction among teachers in CISS and specifically to identify:

a. The level of burnout among teachers in CISS.

b. The level of job satisfaction among teachers in CISS.

c. The relationship between burnout and job satisfaction among teachers in CISS.

\section{Methodology}

The respondents for this study were 175 teachers randomly selected from 5 Chinese Independent Secondary Schools in one of the States of Northern Peninsular Malaysia.

Meanwhile the data for this study was gathered by using a set of questionnaire consist of two sections. The first section measures the teacher burnout by using Maslach Burnout Inventory - Educators Survey (MBI - ES) [22]. The second section of the questionnaires measure teacher job satisfaction by using Job Satisfaction Survey (JSS) [23]. The pilot study findings show that this both instrument has a high reliability with Cronbach alpha values were .82 and .87 respectively.

\section{Findings}

\subsection{The Level of Burnout}

Burnout level in this study was determined based on the categories established by Maslach [22]. Based on the findings from Table 1, the level of teacher burnout for emotional exhaustion and personal accomplishment are moderate and depersonalization was at the low level.

Table 1. Mean score, standard deviation of Burnout.

\begin{tabular}{llll}
\hline Sub-scales of Burnout & Mean & Standard Deviation & Level \\
\hline Emotional Exhaustion & 22.93 & 10.15 & Moderate \\
Depersonalization & 7.74 & 5.68 & Low \\
Personal Accomplishment & 31.26 & 7.47 & Moderate \\
\hline
\end{tabular}

\subsection{The Level of Job Satisfaction}

Based on the Spector [23], the findings from Table 2 show that the overall levels of job satisfaction amongst teachers are at moderate level. Meanwhile all nine job satisfaction dimensions also indicates a moderate level namely pay, promotion, supervision, fringe benefits, contingent rewards, operating procedures, co-workers, nature of work and communication.

Table 2. Mean score, standard deviation of Job Satisfaction.

\begin{tabular}{llll}
\hline $\begin{array}{l}\text { Job Satisfaction } \\
\text { Dimensions }\end{array}$ & Mean & $\begin{array}{l}\text { Standard } \\
\text { Deviation }\end{array}$ & Level \\
\hline Pay & 3.48 & 0.53 & Moderate \\
Promotion & 3.23 & 0.69 & Moderate \\
Supervision & 3.48 & 0.57 & Moderate \\
Fringe Benefits & 3.51 & 0.68 & Moderate \\
Contingent Rewards & 3.43 & 0.74 & Moderate \\
Operating Conditions & 3.07 & 0.79 & Moderate \\
Co-workers & 3.40 & 0.61 & Moderate \\
Nature of Work & 2.93 & 0.61 & Moderate \\
Communication & 3.84 & 0.83 & Moderate \\
Overall Job Satisfaction & 3.37 & 0.38 & Moderate \\
\hline
\end{tabular}

\subsection{Relationship Between Burnout and Job Satisfaction}

The findings of relations between variables were assessed using the Pearson correlation method and findings are displayed in Table 3. 
Table 3. Correlation between Burnout and Job Satisfaction.

\begin{tabular}{lllllllllll}
\hline MBI & JS & PA & PM & SP & FB & CR & OP & CW & NW & CM \\
\hline EE & $-.35^{* *}$ & -.13 & .15 & $-.23^{* *}$ & $-.17^{*}$ & $-.37^{* *}$ & $-.40^{* *}$ & $-.25^{* *}$ & .14 & $-.33^{* *}$ \\
DP & $-.19^{*}$ & -.09 & .02 & -.10 & -.12 & -.13 & -.10 & $-.20^{* *}$ & .11 & $-.30^{* *}$ \\
PA & -.03 & .00 & -.05 & -.04 & -.04 & .06 & -.01 & .01 & $-.19^{*}$ & .06 \\
BO & $-.32^{* *}$ & -.12 & .08 & $-.21^{* *}$ & $-.18^{*}$ & $-.27^{* *}$ & $-.31^{* *}$ & $-.23^{* *}$ & .04 & $-.30^{* *}$ \\
\hline
\end{tabular}

Notes. $* \mathrm{p}<.05, * * \mathrm{p}<.01$

$\mathrm{BO}=$ Burnout, $\mathrm{JS}=$ Overall Job Satisfaction, $\mathrm{PA}=\mathrm{Pay}, \mathrm{PM}=$ Promotion, $\mathrm{SP}=$ Supervision, $\mathrm{FB}=$ Fringe Benefits, $\mathrm{CR}=\mathrm{Contingent} \mathrm{Rewards}, \mathrm{OP}=\mathrm{Operating}$ Procedures, $\mathrm{CW}=$ Co-workers, $\mathrm{NW}=$ Nature of Work, $\mathrm{CM}=$ Communication, $\mathrm{EE}=$ Emotional Exhaustion, $\mathrm{DP}=\mathrm{Depersonalization}, \mathrm{PA}=\mathrm{Personal}$ Accomplishment

The results from Table 3 shows that there is a significant correlation but negative relationship between burnout and overall job satisfaction $(r=-.32, p<.05)$. Meanwhile, there is also a negative significant relationship between burnout dimension of emotional exhaustion with job satisfaction dimension of supervision $(r=-.23, p<.05)$, fringe benefits $(r=-$ $.17, p<.05)$, contingent rewards $(r=-.37, p<.05)$, operating procedures $(r=-.40, p<.05)$, co-workers $(r=-.25, p<.05)$ and communication $(r=-.33, p<.05)$.

On the other hand burnout dimension of depersonalization is also having a negative significant relationship with job satisfaction of co-workers $\quad(r=-.20, \quad p<.05), \quad$ and communication $(r=-.30, p<.05)$.

Finally, burnout dimension of personal accomplishment is found has a significant with job satisfaction dimension of nature of work $(r=-.19, p<.05)$.

\section{Discussion and Conclusion}

Unlike previous findings $[6,24]$, this study found that level of teacher burnout for emotional exhaustion and personal accomplishment were moderate meanwhile the level of teacher burnout for depersonalization was low. On the other hand, the results of this study were similar to those of previous studies $[17,18,25]$ that found the level of job satisfaction is moderate. A possible explanation for this apparent contradiction is due to the difference of the working environment where unlikely previous studies this study used private school teachers as respondents.

Meanwhile consistent with previous studies [15, 19], this findings found that there is a negative significant correlation relationship between burnout and job satisfaction indicating that lower the level of burnout, it would increase a higher job satisfaction among CISS teachers and vice versa. This can be explained by using Maslach [26] theory indicating that when employees are experiencing high levels of burnout, it will then encourage to job dissatisfaction among employees.

This study is the first to test the relationship between burnout and job satisfaction among CISS teachers. Thus the organizational leaders and managers in private school has to promote a happier working environment, interpersonal support, moral support, professional advice, and considerable workload if they want to enhance job satisfaction in their employees. Considering the potentially positive impacts of employees' job satisfaction it would certainly increase their performance, the study also suggests that promoting a positive communications and involving teachers in decision making may impact job satisfaction positively.

\section{References}

[1] Wikipedia. United Chinese School Committees' Association of Malaysia. 2015; Accessed by $5^{\text {th }}$ October 2015 from https://ms.wikipedia.org/wiki/Sekolah_Tinggi_Persendirian_Cina

[2] Dong Zong. United Chinese School Committees'Association of Malaysia. 2015; Accessed by 14 ${ }^{\text {th }}$ October 2015 from http://www.dongzong.my/index.php

[3] Siow Set Fun (2008). Relationship between stress and job satisfaction among assistant principal in Kulai, Malaysia. (Unpublished Thesis). Universiti Teknologi Malaysia.

[4] Aeria L. A. (1998). Burnout among teachers of secondary schools in Petaling. Journal of Educational Three, 2 (2), 79-91.

[5] Antoniou, A. S., Polychroni, F., \& Vlachakis, A. N. (2006). Gender and age differences in occupational stress and professional burnout between primary and high-school teachers in Greece. Journal of Managerial Psychology, 21 (7), 682-690.

[6] Arenawati Sehat Haji Omar, Irdawaty Haji Jaya, \& Mohd Zafian Mohd Zawaawi (2009, March). Study on work stress and burnout among secondary school counselors Kuching, Sarawak. Paper presented in the Conference on Scientific \& Social Research, Malacca, Malaysia

[7] Cherniss, C. (1980). Professional burnout in human service organizations. New York: Praeger.

[8] Byrne, B.M. (1994). Burnout: Testing for the validity, replication and invariance of causal structure across elementary, intermediate and secondary teachers. American Educational Research Journal, 31 (3), 645-673.

[9] Farber, B. A. (1991). Crisis in education: Stress and burnout in the American teacher. San Francisco: Jossey - Bass Publishers.

[10] Tukiran, N. (2014). Assessment literacy among prospective technical teachers in public universities of the South Zone. Universiti Teknologi Tun Hussein Onn Malaysia. (Unpublished Thesis). Universiti Teknologi Tun Hussein Onn Malaysia.

[11] Locke, E. A. (1976). The nature and causes of job satisfaction. In M. D. Dunnette (Ed.), Handbook of industrial and organizational psychology (pp. 1297-1349). Chicago: Rand McNally.

[12] Demirtas, Z. (2010). Teachers' job satisfaction levels. Procedia - Social and Behavioral Sciences, 9, 1069-1073. 
[13] Aziri, B. (2011). Job Satisfaction: A Literature Review. Management Research and Practice, 3 (4), 77-86.

[14] Wong, C. F., \& Tay, A. (2010). Turnover intention and job hoping behavior of music teachers in Malaysia. African Journal of Business Management, 4 (4), 425-434.

[15] Konert, E. (1997). Relationship among middle-school teacher burnout, stress, job satisfaction and coping styles (Unpublished doctoral dissertation). Wayne State University, Detroit.

[16] Tan Sew Lee, (2006). The effect of personality on job satisfaction and teacher job stress. (Unpublished Thesis). Universiti Teknologi Malaysia.

[17] Apandi Omar (2003). Relationship between work stress and job satisfaction among teachers in Secondary School Johor, Malaysia. (Unpublished Thesis). Universiti Teknologi Malaysia.

[18] Lim Yee Chian (2005). Relationship between work stress and job satisfaction among technical teachers in Technical Secondary School Kedah, Malaysia. (Unpublished Thesis). Universiti Teknologi Malaysia.

[19] Anbar, A. \& Eker, M. (2008). An Examination of Relationship between Burnout and Job Satisfaction among Turkish Accounting and Finance Academicians. Europian Jurnal of Economic and Political Studies. 2008. Ejeps-1 (1): 39-57.
[20] Azlina Binti Mohd Kosnin \& Noryati Binti Cheman (2012). The Relationship between work stress and job satisfaction among principal in Melaka, Malaysia. (Unpublished Thesis). Universiti Teknologi Malaysia.

[21] Norul Azlin Binti Ismail (2005). Stress among UPSR teachers in Pendang. (Unpublished Thesis). Universiti Teknologi Malaysia.

[22] Maslach, C., Jackson, S. E., \& Leiter, M. P. (1996). Maslach burnout inventory manual (3rd ed.). Palo Alto, CA: Consulting Psychologists Press.

[23] Spector, P.E. (1985). Measurement of human service staff satisfaction: Development of the job satisfaction survey. American Journal of Community Psychology, 13 (6), 693-713.

[24] Mukundan, J., \& Khandehroo, K. (2010). Burnout among English language teachers in Malaysia. Contemporary Issues in Education Research, 3 (1), 71-76.

[25] Iskandar Padzil, Foo. S. F. \& Ramli Basri (2013). Job satisfaction among teachers in Islamic Secondary School, Malaysia. (Unpublished Thesis). Universiti Putra Malaysia.

[26] Maslach, C. (1982). Burnout: The cost of caring. Englewood Cliffs, NJ: Prentice Hall. 